\title{
Organizational and Pedagogical Conditions for the Development of Social and Communicative Competence of Future Educational Managers
}

\author{
Roza M. Sherayzina $1 *$ [ORCID 0000-0002-7358-0689], \\ Tatyana B. Chugunova 1[ORCID 0000-0001-7121-3693]
}

\author{
${ }^{1}$ Yaroslav-the-Wise Novgorod State University, Veliky Novgorod, Russia \\ Roza.Sherayzina@novsu.ru
}

\begin{abstract}
A modern leader must have not only professional knowledge, but also such important and necessary qualities as purposefulness, energies, a sense of responsibility, sociability, organizational skills, an ability to reflect, i.e. social and communicative competence, which is key in the structure of professional competence of an educational manager and allows for effective communication in the context of social interaction. The aim of the study is to develop, theoretically substantiate and experimentally test the system of organizational and pedagogical conditions for the development of social and communicative competence of master students. The authors set a number of tasks, including clarification of the concept of "social and communicative competence of master students" based on the analysis of scientific research; development of a system of organizational and pedagogical conditions for the development of social and communicative competence of master students; determination of the state and problems in the development of social and communicative competence of master students of the Federal State Budgetary Educational Institution of Higher Education "Yaroslav-the-Wise Novgorod State University" (Veliky Novgorod) on the basis of a diagnostic study; implementation of the system of organizational and pedagogical conditions for the development of social and communicative competence of master students under the "Educational Management" program of the "Pedagogical Education" direction; generalization and description of research results. To solve the set tasks, a system-synergetic approach and the principle of cooperation and corporatism were used. The result of the theoretical part of the research is: clarification of the concept of "social and communicative competence of master students" as the ability of students for effective communication in conditions of social interaction; the structure of the concept under consideration includes four competence-components: communicative competence (the ability to actively interact with people around, to reflect on one's communication tactics), social competence (social interaction), organizational competence (the ability to organize and manage the work of a team), reflexive competence (selfassessment, analysis of one's own activities and activities of colleagues); determination of the system of organizational and pedagogical conditions for the development of social and communicative competence of master students, including regulatory support of educational activities, creation of an information and educational environment, competitive organization of classroom and extracurricular educational activities, monitoring the development of social and communicative competence of master students. The results of the study confirmed the hypothesis that the process of developing the social and communicative competence of master students will be effective if a system of organizational and pedagogical conditions is developed and implemented.
\end{abstract}

Keywords: social and communicative competence; Master's degree program

\section{INTRODUCTION}

The demands of the modern labor market are focused on qualified, competent and competitive professionals who demonstrate willingness to communicate to solve the problems of professional activity, to interact with colleagues and social partners, and lead a team, which puts the problem of high-quality training of professional and pedagogical personnel among the priorities. The order of the 
Government of the Russian Federation dated November 29, 2014 N 2403-r "On Approval of the Fundamentals of the State Youth Policy of the Russian Federation for the Period up to 2025" enshrines the strategic priority of the state youth policy - the creation of conditions for the formation of a harmonious, constantly improving, erudite, competitive, caring personality, capable of adapting to changing conditions and receptive to new creative ideas.

The study of the international organizations Global Education Futures and World Skills Russia ("Skills of the future: what one needs to know and be able to do in a new complex world") presents the basic skills of the XXI century, which include: emotional intelligence and empathy (the need for cooperation, the development of a human-centered economy); cross-cultural identity; ability to learn (and self-teach). These skills prove that communication and interaction with people will not lose their relevance, which in turn determines the importance of developing the social and communicative competence of university students.

The Federal State Educational Standard of Higher Education (higher education level - Master's degree) in the field of training 04.04.01 Pedagogical education (order N 126 of February 22, 2018) defines the results of mastering the Master's program, which include formation of universal and general professional competencies. Professional competencies are established by the Master's program and are formed on the basis of professional standards that correspond to the professional activities of the graduate.

The main professional educational program of Master's degree in the "Pedagogical education" field of training, the profile "Educational management" fixes the pedagogical, project and organizational and managerial types of tasks of the professional activity of graduates, each of which implies the possession of social and communicative competence, the ability to organize social interaction. The main professional educational program also presents competencies that must be formed in a graduate as a result of its development, a number of which are focused on the formation of social and communicative competence:

- universal competencies of graduates (teamwork and leadership, communication, intercultural interaction);

- general professional competencies of graduates (joint and individual educational and educational activities of students, interaction with participants in educational relations);

- professional competence of graduates (planning and organizing the activities of groups, the inclusion of educators and students in a variety of socio-cultural practices, joint activities, leisure and socially significant events).

At the same time, despite the orientation towards the development of social and communicative competence of students declared in the program documents, the analysis of the results of pedagogical research (M.P. Trofimenko, G.V. Kravets, etc.) indicates insufficient readiness for this type of activity: the lack of empirical research of the real state of social and communicative competence of master students; the spontaneous formation of social and communicative competence as an accompanying component of the professional training of a future teacher.

The concept of "social and communicative competence" is more often interpreted in Russian sources; in foreign literature, a distinction is made between "social competence" $[1,2]$ and "communicative competence" [3-5].

Various areas of studying the social and communicative competence of students are devoted to the works of G.V. Kravets [6] (social and communicative competence as a personality trait, reflecting its achievements in the development of relationships with other people), L.V. Orinina and I.V. Kashuba [7] (social and communicative competence as the activity of students to master the skills of effective communication in the context of social interaction), M.P. Trofimenko [8] (social and communicative competence of students of pedagogical specialties of the university as an ability for effective social contacts, for a high degree of professional and social adaptation).

The authors of the article investigate the problem of forming a system of organizational and pedagogical conditions for the development of social and communicative competence of master students. The paper deals with the following research questions:

- what is the structural and content characteristic of the concept of "social and communicative competence of master students";

- what components should be included in the system of organizational and pedagogical conditions for the development of social and 
communicative competence of master students;

- what results will the use of the proposed system give in the process of educational and extracurricular activities of 1 st and 2 nd year master students at the university.

\section{MATERIALS AND METHODS}

The aim of the study is to develop, theoretically substantiate and experimentally test the system of organizational and pedagogical conditions for the development of social and communicative competence of master students.

Research objectives:

1) Clarifying the concept of "social and communicative competence of master students" based on the analysis of scientific research.

2) Developing a system of organizational and pedagogical conditions for the development of social and communicative competence of master students.

3) Determining the state and problems in the development of social and communicative competence of master students under the program "Educational Management" of the "Pedagogical Education" direction of training.

4) Implementing the system of organizational and pedagogical conditions for the development of social and communicative competence of master students under the program "Educational Management" of the "Pedagogical Education" direction of training.

5) Summarizing and describing the research results.

The methodological basis of the system is the systemic-synergetic approach $[9,10]$ to the process of developing the social and communicative competence of master students. In the context of our research, the choice of this approach is explained by the fact that the process of developing social and communicative competence is based on the implementation of a system for including undergraduates in different types of group educational and extracurricular activities.

The use of a systemic-synergetic approach as a methodological basis for the development of social and communicative competence of students made it possible to organize work in groups and teams in the system of "educational - extracurricular activities" in order to form such components of social and communicative competence as: communicative competence (the ability to actively interact with people around, to reflect on their communication tactics), social competence (social interaction), organizational competence (the ability to organize and manage the work of a team), reflexive competence (self-assessment, analysis of one's own activities and colleagues). The implementation of this approach involves a step-by-step adjustment of group and team activities; organization of multilevel teams; joint active discussion of various pedagogical problems in classroom and extracurricular classes based on a discussion under the guidance of a teacher and a tutor. The implementation of the system-synergetic approach took into account the peculiarities of the interaction of master students and teachers, aimed at the formation of social and communicative competence to form their readiness for new types of activity (project, expert, socialreflective and creative).

The above described characteristic of the systemic-synergetic approach allows one to formulate the basic principle, in accordance with which our system for the development of social and communicative competence of undergraduates is built - the principle of cooperation and corporate training.

We consider this principle as a joint interaction of master students for the development of social and communicative competence in design, scientific, social, and creative activities. The principle of cooperativity and corporatism is implemented through the organization of various types of joint activities to solve common problems in groups using interactive technologies.

Implementation of the principle of cooperativity and corporatism takes into account the peculiarities of group work technologies; ensuring positive interdependence in the group (social relations, communication, favorable moral and psychological climate); features of self-esteem as an important component of communication skills; the subject position of everyone in the educational organization; opportunities for socialization and communication in groups (in pairs). Cooperation and corporatism is a significant characteristic of the interaction of teaching staff, which contributes to the improvement of social relations and the moral and psychological climate in the team $[11,12]$. 
Within the framework of this principle, the teacher acts as a mentor in teaching students, and the student participates in the learning process, which makes the student and teacher partners in the educational process.

To collect and analyze the data, the following empirical research methods were used: questionnaires (testing) of master's students of 1 and 2 courses of full-time and part-time education, ascertaining, forming and control experiments.

The experiment to implement the system of organizational and pedagogical conditions for the development of social and communicative competence of master students was carried out in three stages: ascertaining experiment (conducting entrance diagnostics of 1 st and 2nd year undergraduates in order to determine the initial level of social and communicative competence of students); formative experiment (development of social and communicative competence of master students in accordance with the system of organizational and pedagogical conditions formulated by the authors); control experiment (conducting control diagnostics, the purpose of which is to identify the effectiveness of the system of organizational and pedagogical conditions for the development of social and communicative competence of master students).

The processing of experimental data was carried out according to the indicators of the development of social and communicative competence: readiness for communication, for social interaction, organization and management of team work, reflection.

\section{RESULTS}

Theoretical and methodological research of the development of social and communicative competence of master students allows one to formulate the main conclusions.

The concept of "social and communicative competence of master students" has been clarified on the basis of the analysis of scientific research and taking into account the peculiarities of the educational process in the Master's degree program. The "social and communicative competence of master students" refers to the ability of students to communicate effectively in the context of social interaction.

The structure of the concept of "social and communicative competence of master students" includes four components-competencies: communicative competence (the ability to actively interact with people around, to reflect on their communication tactics), social competence (social interaction), organizational competence (the ability to organize and manage the work of a team), reflexive competence (self-assessment, analysis of one's own activities and activities of colleagues).

The system of organizational and pedagogical conditions for the development of social and communicative competence of master students has been determined, including the regulatory and legal support of educational activities, the creation of an information and educational environment, the competitive organization of classroom and extracurricular educational activities, monitoring of the development of social and communicative competence of master students. The conceptual and methodological basis of the development of social and communicative competence is the systemicsynergetic approach and the principle of cooperation and corporatism, which allow students to be included in the educational process. The student's activity makes it possible to impart a communicative, activity-oriented and interactive character to the educational process of professional training of a teacher.

Within the framework of the ascertaining experiment, the following problems were identified: firstly, undergraduates have an average level of readiness for communication $(52 \%$ of students do not know and do not know how to use modern communication technologies in professional communication, do not know how to reflect on their communication tactics and summarize the speech behavior of the interlocutor); secondly, $60 \%$ of master students have medium and low levels of readiness for social interaction (they do not know how to successfully interact with classmates and teachers); thirdly, an insufficient level of readiness of undergraduates to organize and manage the work of a team was noted (28\%); fourthly, students are not ready for reflection - self-analysis of their own activities and the activities of their classmates (35\%).

In the process of the formative experiment, a system of organizational and pedagogical conditions for the development of social and communicative competence of master students at the Department of Primary, Preschool Education and Social Management was implemented.

The results of the control experiment testify to the positive dynamics of the process of developing the social and communicative competence of master 
students, which confirms the effectiveness of the implementation of the system of organizational and pedagogical conditions: the level of development of communicative competence increased to $76 \%$ (the ability to actively interact with people around, to reflect on their communication tactics), the level of development social competence $-75 \%$ (social interaction), the level of development of organizational competence $-79 \%$ (the ability to organize and manage the work of a team), the level of development of reflexive competence - $81 \%$ (self-assessment, analysis of their activities and the activities of colleagues).

\section{DISCUSSION}

The interpretation of the results obtained in the course of the research in the context of already published works on the research problem testifies to the scientific novelty, which consists in the fact that for the first time the system of organizational and pedagogical conditions for the development of social and communicative competence of master students has been determined and substantiated. It has been proven that purposeful activity in the Master's degree program on the formation of social and communicative competence of students is effective: $70 \%$ of master students of the profile "Educational Management" who took part in the experiment on the formation of social and communicative competence, graduated from the Federal State Budgetary Educational Institution of Higher Education "Yaroslav-the-Wise Novgorod State University" (NovSU) with honors and got a job in educational organizations of preschool, secondary and higher education of the Novgorod region, education committees, which confirms the competitiveness of the graduates. In order to activate organizational and social competencies, master students have developed electronic teaching aids.

The created information and development educational environment $[13,14]$ created conditions for the development of the project "Storytelling as a tool for adaptation of young specialists" by the master students, which is focused on the formation of social and communicative competence. According to the results of the survey, it was revealed that $87.7 \%$ of teachers consider stories from the lives of experienced colleagues an important source of information that contributes to the adaptation of novice specialists. In order to form social and communicative competence, master students from NovSU took part in the research seminar "Psychological and pedagogical technologies for the development of leadership qualities of teachers and students". The preparation of reports and speeches at the international conference contributed to the development of communication skills among the undergraduates (the ability to put forward arguments and adapt the presentation of ideas in relation to the audience, to promote familiarization of the general public with the problem under study).

\section{CONCLUSION}

The article presents the results of research on the development of social and communicative competence of master students. A theoretical and experimental study of the process of developing the social and communicative competence of master students (future educational managers) has been carried out. A system of organizational and pedagogical conditions for the development of social and communicative competence of master students was implemented, which made it possible to increase the level of social and communicative competence in its main components. The effectiveness of the optimal combination of selfactualization, self-organization, self-development, self-education and group activity is reflected in the results of students' participation in competitive and grant activities, active publishing, etc.

The theoretical significance of the research: the theory and methodology of vocational education is enriched with modern knowledge about the essence of the concept of "social and communicative competence of master students" and its components, which complements the general concept of training master students as highly qualified specialists in the field of "Pedagogical education".

The practical significance of the study indicates that the system of organizational and pedagogical conditions for the formation of social and communicative competence contributes to: the development of skills of interaction with people around, the ability to reflect on their communicative competence, to organize and manage the work of a team, to conduct self-assessment, analysis of their activities and the activities of their colleagues. The developed system can be used in the practical activities of Russian and foreign universities.

The study does not cover the entire list of issues related to the development of social and communicative competence of master students. One of the promising areas for further research can be the development of scientific research competence of 
students in the "bachelor's - master's - postgraduate studies" system.

\section{AUTHORS’ CONTRIBUTIONS}

The research concept was developed by Roza M. Sherayzina. Theoretical and practice-oriented parts of the text were written by Roza M. Sherayzina, Tatyana B. Chugunova.

\section{REFRENCES}

[1] M.V. Sleptsova, "Formation of students' social competence in a virtual educational environment", Education and Information Technologies, Springer, 2019, vol. 24, pp. $743-$ 754. DOI: $10.1007 / \mathrm{s} 10639-018-9798-\mathrm{Z}$

[2] I. Plevova, L. Kremenkova, M. Pugnerova, "Social competences of university students in relation to personality characteristics and forms of study", in ICERI Proceedings, 2018, pp. 1733-1740. DOI: 10.21125 /iceri.2018.1388

[3] I. Garcia-Martinez, B. Sierra-Arizmendiarrieta, R. Quijano-Lopez, M. Perez-Ferra, "Communicative Competence in Student Teaching Degrees: A Systematic Review", Publicaciones, 2021, vol. 50(3), pp. 37-54. DOI: 10.30827/publicaciones.v50i3.15744

[4] O.L. Nazarova, S.V. Rudakova, T.V. Akasheva, S.S. Velikanova, A.A. Bakholskaia, O.P. Chernykh, "The development of communicative competence of university students in the process of their professional training", Praxis Educacional, 2019, vol. 15(36), pp. 599-609. DOI: 10.22481/praxisedu.v15i36.5936

[5] D. Bjekic, L. Zlatic, M. Bojovic, "Studentsteachers' communication competence: basic social communication skills and interaction involvement", Journal of Educational Sciences \& Psychology, 2020, vol. X(LXXII(1)), pp. 2434.

[6] G.V. Kravets, "The problem of the formation of social and communicative competence of modern students", [Problema formirovaniya social'no-kommunikativnoj kompetentnosti sovremennyh studentov], in Proceedings of the III ISPC with the participation of students, 2020, pp. 338-342. (In Russ.).
[7] L.V. Orinina, I.V. Kashuba, "Formation of social-communicative competence of higher education students", Humanitarian and Pedagogical Research, 2018, vol. 2(3), pp. 1115. (In Russ.).

[8] M.P. Trofimenko, "Formation of social and communicative competence of students of pedagogical specialties of the university in the process of vocational training" [Formirovanie social'no-kommunikativnoj kompetentnosti studentov pedagogicheskih special'nostej vuza v processe professional'noj podgotovki], Abstract of the $\mathrm{PhD}$ in Pedagogic Sciences thesis: 13.00.08, Moscow, 2013, 29 p. (In Russ.).

[9] R.S. Nagovitsyn, M.V. Saltykova, M.V. Maksimova, "A synergistic approach to the promotion of foreign students' socialization and adaptation to the educational environment of higher educational institutions", Novosibirsk State Pedagogical University Bulletin, 2018, vol. 8(6), pp. 7-22. (In Russ.). DOI: 10.15293/2226-3365.1806.01

[10] O.L. Nazarova, A.L. Soldatchenko, S.V. Rudakova, "Implementing the continuousand-synergetic approach to social maturity formation in college students", Perspectives of Science and Education, 2018, vol. 36(6), pp. 3647. (In Russ.). DOI: 10.32744/pse.2018.6.4

[11]A. Bain, L. Zundans-Fraser, "The SelfOrganizing University: Designing the Higher Education Organization for Quality Learning and Teaching", Singapore: Springer Nature Singapore Pte Ltd., 2017, 192 p. DOI: 10.1007/978-981-10-4917-0

[12] M.N. Pevzner, R.M. Sheraizina, I.A. Ushanova, P.A. Petryakov, I.A. Donina, "Concepts and strategies of cultural diversity management at higher school", Espacios, 2017, vol. 38(50), p. 29.

[13] M.N. Pevzner, P.A. Petryakov, I.A. Donina, N.A. Shaydorova, "Internet Marketing as a Diversity Management Tool in Education", European Research Studies Journal, 2018, vol. 21(3), pp. 496-505. DOI: 10.35808/ersj/1078

[14] W.P. Racine, "Social identity development and the situation of scientists and engineers as new leaders", Journal of Leadership Studies, 2015, vol. 9(3), pp. 23-41. DOI: 10.1002/jls.21398 